IJAMSR 3 (2) www.ijamsr.com CrossRef: https://doi.org/10.31426/ijamsr.2020.3.2.3112

\title{
The Effectiveness of Entrepreneurship Development Program through Project-Based Learning Model to Entrepreneurial Soul of College Students
}

\author{
Suharto ${ }^{1}$, Tri Wahyuni Maduretno ${ }^{2}$ \\ 1,2 STKIP PGRI Nganjuk, Jl.A.R. Saleh No.21, Jawa Timur, Indonesia \\ Email: suharto@stkipnganjuk.ac.id
}

Keywords:

Entrepreneurship,

Project Based Learning,

Entrepreneurial Soul

\begin{abstract}
A B S T R A C T
Entrepreneurship education is very important for students to face competition era in the Industrial Revolution 4.0. The need for innovative programs so as to encourage student entrepreneurship. The purpose of this study to determine the effectiveness of entrepreneurship development programs through projectbased learning model to entrepreneurial soul of students in Higher Education. The research sample of 72 students who have followed the course Entrepreneurship in STKIP PGRI Nganjuk, Indonesia. Collecting data using questionnaires, tests, and documentation. Statistical test studies using simple regression test that aims to determine the effect of independent variables on the dependent variable. The results showed that (1) implementation of projectbased learning model in both categories with an average percentage of 79.09\%; (2) the entrepreneurial soul of students in both categories with an average percentage of $81.82 \%$. The analysis also showed that the projectbased learning model effectively applied to improve entrepreneurial soul of students. The significant differences also occurred on the willingness of student entrepreneurs from 2017 up to 2019. In 2017 achieved by 38\%, increased in 2018 by 43\%, and in 2019 amounted to 69.33\%. In its application, the student is able to significantly increase the power of creativity and innovation in creating products that fit market needs.
\end{abstract}

Citation: Vera Septi Andrini (2020). The 3-Dimensional Hologram on Biophysics Learning: International Journal of Advanced Multidisciplinary Scientific Research (IJAMSR) ISSN:2581-4281, 3 (2), February, 2020, pp $13-25$ 
IJAMSR 3 (2) www.ijamsr.com CrossRef: https://doi.org/10.31426/ijamsr.2020.3.2.3112

\section{Introduction}

In the era of industrial revolution 4.0 today, the business sector and entrepreneurship has developed very rapidly. A big jump has occurred in the world of entrepreneurship, especially where the industry sector of information and communication technologies take the leading role. Entrepreneurship is a tool for self-development that is able to provide a basis for establishing social or commercial activity (Directorate-General, 2008; Lindh \& Thorgren, 2016; Roche, 2014). Referring to this, the college's involvement is vital in supporting the concept of modern entrepreneurs, generate skilled entrepreneurs. Higher education is a major source of knowledge and human capital in building innovation, entrepreneurship, and productivity Naderi, N., Saeed, R., \& Ahmad, RNI (2013).

STKIP PGRI Nganjuk seeks to provide students with a variety of entrepreneurial programs, well-integrated with the compulsory subjects in each course and through the activities of the Student Creativity Program (SCP). From the activities carried out, has a lot of product produced. For example, in the field of food and beverage products such as rice Mercon Five Corners, red onion flakes
(KRIBAW), mushrooms krispi, nuggets Know, sampeu Croisant Alus (SASANT) with basic processed cassava, Jamu Traditional, teh tarik, and more. Livestock and agricultural fields such as cultivation of onion, dragon fruit, Jowo Super chicken (JOPER), Raising catfish, Goat, Duck, Bird Lovebird, and Cattle. In services such as tutoring, service HP, and others.

However, the actual number of students who are self-employed in 2018 is still far from the target. The following are the achievement of performance indicators on the number of students who were self PGRI STKIP Nganjuk began in 2017 until 2019.

Based on Figure 1, the target student entrepreneurs owned by 100 while the realization only reached 38 . This means that only $38 \%$ achievements. In 2018, targeted 120 while the achievements of realization of 52 . Achievement of 43\%. Of course in 2018 there was an increase of 5\%. Achieving this target is still lacking considering the many programs that have been held. Even if the review of Student Creativity Program in 2018, only six groups of students who qualify for funding. The results of the data analysis showed that the entrepreneurial skills of students in STKIP PGRI Nganjuk 2017 until 2018 showed that 
more than $50 \%$ prefer to seek jobs rather than create jobs.

Referring to the issues raised and the low interest in entrepreneurship for students in STKIP PGRI Nganjuk, we need to hold selfemployment programs are able to provide stimulus. Therefore, in 2019 a lecturer in entrepreneurial team working to improve the ability of students in entrepreneurship focused on two things: the implementation of more innovative learning model-based product such as project-based learning model. Project-based learning strategy had recently been recognized by many people to improve potency and suitable in developing the creativity of learners (Ravitz et al. (2011); Wurdinger \& Qureshi (2015). In addition, also held product exhibition bazaar activity program at the end of the learning process.

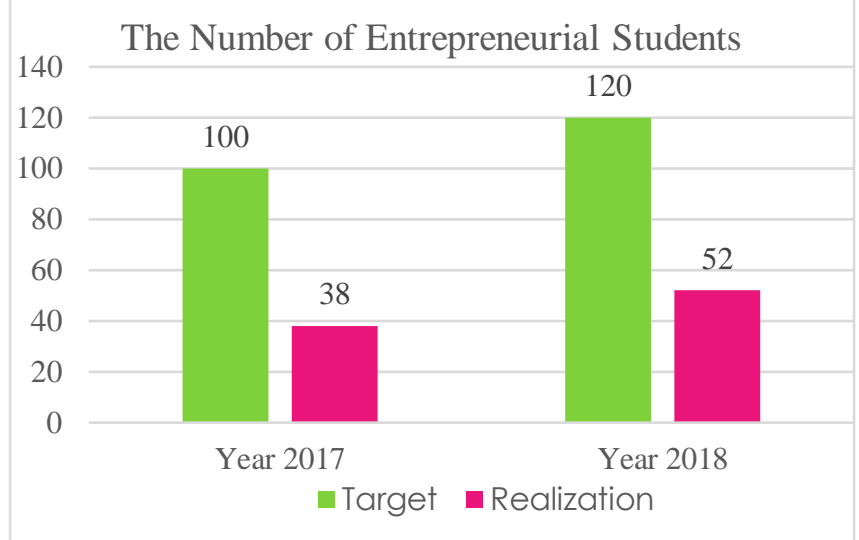

Figure 1: Data of Student Entrepreneurship Start Year $2017 \mathrm{~s} / \mathrm{d}$ in 2018
Implementation of project-based learning model in the learning process in the subject of entrepreneurship is very effective in motivating students. According Vanevenhoven and Liguori (2013), project-based learning easier for students to learn the concept of due processes through which systematically arranged and produced products. then, according toAyobami \& Olakitan (2011), project-based learning design is able to support the students in creating a product that can be realized business done. Meanwhile, according Pazhani \& Priya (2012), project-based learning can improve the creative abilities of learners, collaboration skills, and soft skills. Softskill always associats with a person's skills in dealing with others (interpersonal skills) and skills in organizing themselves (intrapersonal skills). Through project-based learning model, the ability of interpersonal and intrapersonal will develop optimally.

Project-Based Learning ( $\mathrm{PjBL})$ is a learning model that has a project-based outcomes. In application, this model involves students to design, create, and display products to solve problems more real (Sani, 2014). Wurdinger, S., \& Qureshi, M. (2015), stating that the model project-based learning to effectively promote creativity. This model requires 
students to work in real time, to solve the problem with the solution in the form of a product or works in practice. The basic principle of project-based learning models are: (1) The learner-centered learning which involves tasks in real life; (2) task-oriented research projects with the theme that has been determined, and; (3) The investigation carried out in an authentic and based on the product or the work. The next step, The product is communicated to elicit a response and feedback for improvement next project. Syntax projectbased learning are as follows: (1) the determination of the project, (2) planning steps completion of the project, (3) monitoring facilities of teachers and the preparation of project implementation schedule, (4) preparation of the report and presentation/publication of the project results, (5 ) Evaluation of the process and project results.

The problems were taken in this study to determine the effectiveness of the development program entrepreneurship through projectbased learning model to entrepreneurial soul of college students. Entrepreneurship is a way to develop the ability and individual ideas to be converted into a commercial action (Lukic, 2012). Common characteristics entrepreneurship or referred to entrepreneurial soul can be seen from various aspects personality in each individual, such as soul, character and behavior. More details include a sense of confidence and optimism, orientation on tasks and results, risk-taking, good leadership, has originality, future-oriented, desire to move forward, strong curiosity, and has a high spirit (Sunarya et al. (2011); Zimmerer et al., 2008).

\section{Methods and Materials:}

The experiment was conducted in STKIP PGRI Nganjuk. The study design using a quantitative approach. These samples included 72 students consisting of 5 courses that have followed the entrepreneurship courses that economic education department, mathematics education department, English education department, civics education department and science education department. The independent variable in this study is the Model ProjectBased Learning. The dependent variable is the soul entrepreneurship. The data collection technique using documentation, questionnaire, and test. A questionnaire was used to obtain data on model of project-based learning and soul entrepreneurship. While the tests used to measure student ability and mental 
entrepreneur. Research using descriptive analysis. Statistical test studies using simple linear regression analysis.

It should be complete enough to allow experiments to be regurgitated. All the same, only truly new tactics ought to be reported in detail; previously posted strategies must be referred to, and critical modifications of published approaches should be adverted to in brief. Subheadings have to be applied.

\section{Results and Discussion:}

\section{Table 1: Distribution Achievement}

Indicators Project Based Learning

\section{Implementation Model}

\begin{tabular}{|l|c|c|}
\hline \multicolumn{1}{|c|}{ Indicator } & \multicolumn{1}{|c|}{$\begin{array}{c}\text { The mean } \\
\text { percentage of } \\
\text { Achievement }\end{array}$} & Category \\
\hline Determining Project & 84.09 & Very good \\
\hline $\begin{array}{l}\text { Facilities, lecturers and } \\
\text { monitoring project } \\
\text { implementation schedule }\end{array}$ & 79.55 & Well \\
\hline $\begin{array}{l}\text { Step-by-step completion of the } \\
\text { project }\end{array}$ & 72.73 & Well \\
\hline $\begin{array}{l}\text { Publication of the results of the } \\
\text { project }\end{array}$ & 81.82 & Well \\
\hline Evaluation of project results & 77.27 & \\
\hline
\end{tabular}

Source: Data processed

Based on Table 1, the achievement of the application in terms of determining the project idea by $84.09 \%$ (excellent category). The idea of a student project created a very interesting and quite innovative as venture Mini Pizza Home Made, Sate cilok Contents Crispy, fried meatballs, various products of t-shirts, various dairy products and cakes. Facilities, lecturers and monitoring project implementation schedule achievement amounted to 79.55 (both categories). Students in detail implement the project according to the planned schedule. Submarine project implementation period 1 semester followed by students taking entrepreneurship courses. Steps the achievement project completion by 72.73 (both categories). At this stage there are different ways of each group of students in the completion of the project. Step completion of the project begins with making the manufacture of the product, the packaging manufacturing, to marketing stage. Publication of the results of the project amounted to 81.82 the achievement (both categories). Publication of the results of student projects directed in the form of scientific articles and the target can be published in the journal. Evaluation of the results of the project amounted to 77.27 the achievement (both categories). The evaluation was conducted between students and accompanied by a lecturer of the course. It is intended to make improvements of the whole process has been carried out. 27 (both 
IJAMSR 3 (2) www.ijamsr.com CrossRef: https://doi.org/10.31426/ijamsr.2020.3.2.3112

categories). The evaluation was conducted between students and accompanied by a lecturer of the course. It is intended to make improvements of the whole process has been carried out. 27 (both categories). The evaluation was conducted between students and accompanied by a lecturer of the course. It is intended to make improvements of the whole process has been carried out.

The Project-Based Learning model is applied in the learning process in Entrepreneurship courses because this model trains students to be active, creative, and innovative in producing tangible products (Lillian, B. (2012); Pratama \& Prastyaningrum, (2019). In making projects, students are required to carry out activities starting from the production stage to the sales stage. Even students must publish project results in the form of scientific articles. These activities can of course train various abilities such as communication and promotion practices, planning and creating products, and finding market opportunities. Thus, entrepreneurship skills students will really be well honed. The role of the lecturer is only as a facilitator and evaluating the product. When students work on project assignments, investigative activities can be carried out in collaborative groups that are organized by product type. Kills such as planning products, negotiating, gathering information, and the division of tasks a team needs in investing. Furthermore, the results of information based on market opportunities will trigger students to create new products that are more creative and needed by consumers.

Table 2: Data Distribution Indicators of Entrepreneurship Spirit Achievement

\begin{tabular}{|l|c|c|}
\hline \multicolumn{1}{|c|}{ Indicator } & $\begin{array}{c}\text { The mean } \\
\text { percentage of } \\
\text { Achievement }\end{array}$ & Category \\
\hline $\begin{array}{l}\text { Confident and } \\
\text { Optimistic }\end{array}$ & 88.64 & $\begin{array}{l}\text { Very } \\
\text { high }\end{array}$ \\
\hline $\begin{array}{l}\text { Task-oriented } \\
\text { and results }\end{array}$ & 84.09 & $\begin{array}{l}\text { Very } \\
\text { high }\end{array}$ \\
\hline Dare to take risks & 90.91 & $\begin{array}{l}\text { Very } \\
\text { high }\end{array}$ \\
\hline $\begin{array}{l}\text { Having } \\
\text { leadership }\end{array}$ & 79.55 & High \\
\hline $\begin{array}{l}\text { Having } \\
\text { keorisinalitasan }\end{array}$ & 72.73 & High \\
\hline $\begin{array}{l}\text { Oriented to the } \\
\text { future }\end{array}$ & 81.82 & High \\
\hline $\begin{array}{l}\text { Desire to move } \\
\text { forward }\end{array}$ & 75.00 & High \\
\hline Curiosity strong & 79.55 & High \\
\hline $\begin{array}{l}\text { Having a high } \\
\text { unyielding spirit }\end{array}$ & 84.09 & $\begin{array}{l}\text { Very } \\
\text { high }\end{array}$ \\
\hline
\end{tabular}

Based on Table 2, the achievement entrepreneurship soul can be observed based on nine indicators. Indicators of achievement confidence and optimism reached $88.64 \%$ (very high category). Student confidence increases 
with a given learning model. Students are becoming more optimistic that the ready made and ready made products to compete. This capability is important because it is the main capital for an entrepreneur. Achievement indicators and results-oriented task of $84.09 \%$ (very high category). This indicator was observed under the rubric of assessment tasks. The results show that students are more focused in finishing products that are already planned. Evaluation of the task, improvements, and suggestions made by the lecturer once every week.

Achievement indicators of risk-taking by $90.91 \%$ (very high category). Calculation of the products owned and a strong commitment to promote products encourage students to strive to find opportunities to obtain the desired result (Kusmintarti, A., Thoyib, A., Maskie, G., \& Asr, K. (2016). the evaluation results showed, in product sales stage 1 there were 34 students who suffered losses. However, here the role of the lecturer to provide reinforcement and encouragement. as a result the students make more products with additional innovation both from the appearance of the product, packaging, pricing, and various promotional model. According to Angelita S. Bajaro, "an entrepreneur who dared to risk are people who always want to win and win in a good way" (Yuyun Wirasasmita, in Suryana, 2003: 21). Achievement indicators have leadership of $79.55 \%$ (high category). Ability in leadership reflected the ability of students in groups. Not as a dictator but as a supervisor in charge of advising, encouraging, directing, and pays tribute to the team that can achieve employment targets.

Achievement indicators have the originality of $72.73 \%$ (high category). Achievement indicators desire to move forward $75.00 \%$ (high category). Keorisinalitasan and desire to move forward in question is the ability of an entrepreneur to develop new ideas, doing new things, to do many things with a good knowledge of, and ability to find opportunities in entrepreneurship. The desire to progress and high motivation in completing tasks better and faster than the previous lenih (Kusmintarti, A., Thoyib, A., Maskie, G., \& Asr, K. (2016) and Greenberg, J. \& Baron, RA (2008). In this case, a lot of students who have tried the new creation in developing business ideas. new creations include products, packaging, and marketing. Indonesia).Achievement-oriented indicators in the future by $81.82 \%$ (high category). At this stage, students are equipped with the passion, vision, and targets. The 
IJAMSR 3 (2) www.ijamsr.com CrossRef: https://doi.org/10.31426/ijamsr.2020.3.2.3112

success of an entrepreneur is not solely based on the amount of turnover, but rather the ability to sustain the business in the face of change with the times. Therefore, by holding workshops equip faculty entrepreneurship by bringing experts and alumni entrepreneurs who have been successful entrepreneurship. Experts and alumni were tasked with providing the passion and knowledge of the students towards entrepreneurial skills.

Achievement indicators curiosity strongly at $79.55 \%$ (high category). Achievement indicators have unyielding spirit high of $84.09 \%$ (very high categories). Curiosity and unyielding spirit is the main asset an entrepreneur to find something for the betterment of the business and achieve maximum results. Trying to find more information to reduce uncertainty and error (Zarei, E., Zainalipour, H., \& Shahraki, LS (2013). At this stage, students are asked to find a successful entrepreneurial character and conduct interviews for dig up capabilities and increase knowledge. It this is intended to add to the student experience.
Table 3: Simple Regression Test Results

\begin{tabular}{|c|c|c|c|c|c|}
\hline \multirow[b]{3}{*}{ Model } & \multicolumn{5}{|c|}{ Coefficients } \\
\hline & \multicolumn{2}{|c|}{$\begin{array}{c}\text { Coefficien } \\
\text { ts } \\
\text { unstandar } \\
\text { dized }\end{array}$} & \multirow{2}{*}{\begin{tabular}{|c|}
$\begin{array}{c}\text { standard } \\
\text { ized } \\
\text { Coeffici } \\
\text { ents }\end{array}$ \\
beta
\end{tabular}} & \multirow[b]{2}{*}{$\mathrm{t}$} & \multirow[b]{2}{*}{$\begin{array}{l}\mathrm{Si} \\
\mathrm{g} .\end{array}$} \\
\hline & $\mathrm{B}$ & \begin{tabular}{|l|} 
Std. \\
Error \\
\end{tabular} & & & \\
\hline 1 (Constant) & $\begin{array}{r}64 \\
717 \\
\end{array}$ & 4885 & & $\begin{array}{r}13 \\
247 \\
\end{array}$ & .0 \\
\hline $\begin{array}{l}\text { Project_Based_L } \\
\text { earning }\end{array}$ & .190 & .080 & .273 & $\begin{array}{r}2,3 \\
77\end{array}$ & 20 \\
\hline $\begin{array}{l}\text { a. Dependent Varia } \\
\text { Jiwa_Enterpreuners }\end{array}$ & & & & & \\
\hline
\end{tabular}

Statistical analysis showed that the significance value (Sig.) Of 0,020 is smaller than the probability of 0.05 . Therefore we can conclude that $\mathrm{HO}$ is rejected and $\mathrm{Ha}$ accepted, which means that there is the influence of entrepreneurship development program through project-based teaching model to student entrepreneurship spirit.

Table 4: The amount of Variables Influence Of Variable Bound

\begin{tabular}{|l|c|r|r|r|}
\hline \multicolumn{5}{|c|}{ Model Summary } \\
\hline Model & R & $\begin{array}{c}\text { R } \\
\text { Square }\end{array}$ & $\begin{array}{c}\text { Adjusted R } \\
\text { Square }\end{array}$ & $\begin{array}{r}\text { Std. Error of } \\
\text { the Estimate }\end{array}$ \\
\hline 1 & $.673 a$ & .751 & .617 & 2219 \\
\hline \multicolumn{5}{|l}{$\begin{array}{l}\text { a. Predictors: (Constant), } \\
\text { Project_Based_Learning }\end{array}$} \\
\hline
\end{tabular}


IJAMSR 3 (2) www.ijamsr.com CrossRef: https://doi.org/10.31426/ijamsr.2020.3.2.3112

Based on Table 4. known value of $\mathrm{R}$ Square of 0.751. This value implies that influence entrepreneurship development programs through project-based learning model to student entrepreneurship soul amounting to $75.1 \%$, while $24.9 \%$ are influenced by other variables not examined.

Education in the era of industrial revolution 4.0 challenging plays an important role in the preparation of students. The concept of learning is integrated with the values entrepreneurship is the answer to implement creative ideas in the face of developments. Students not only learn the theory but also learn the real challenge. Through Project-based learning models, students will be used to carry out a real product-based learning, planning, and to the marketing stage. This learning model is able to provide an opportunity for the students actively internalize the values entrepreneurship through project tasks given.

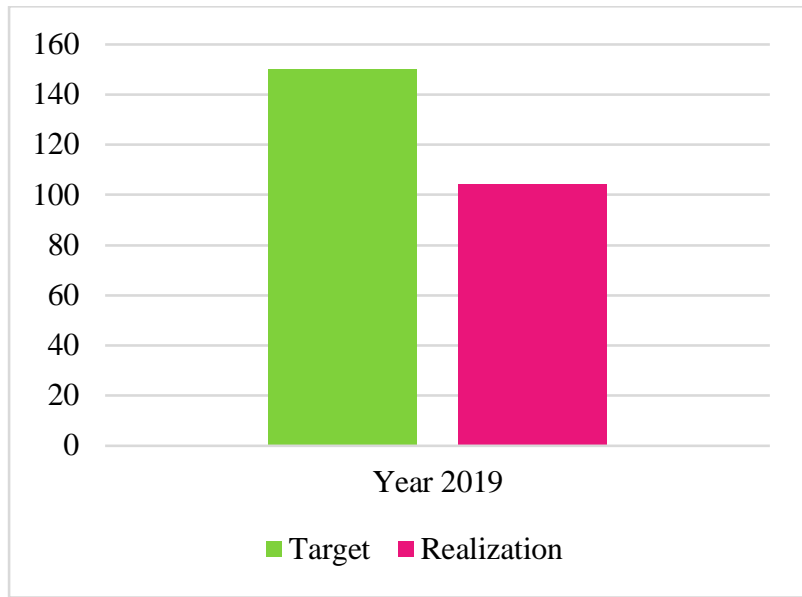

Figure. 1: Entrepreneurship Student Data In 2019

Based on Figure 1, In 2019 is targeted to the number of students that entrepreneurship is 150 while the realization of 104 students. This means that the achievement of the target of $69.33 \%$. When compared with data on the number of students in entrepreneurship in 2017 and 2018, then in 2019 it has increased very significantly. More details can be seen in Figure 2.

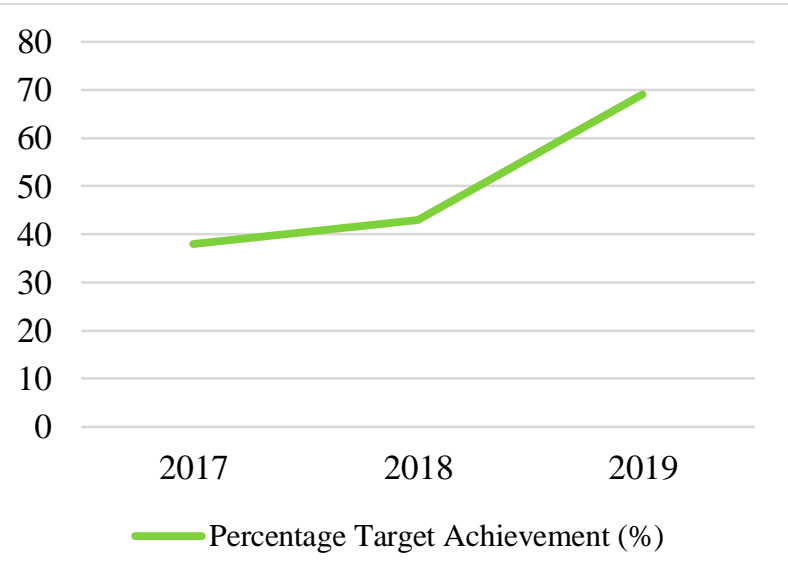

Figure 2: Percentage Target Achievement Number of Students Entrepreneurship Year 2017-2019 
Based on Figure 2, can be seen the percentage began in 2017 until 2019 always increase. In 2017 the percentage of achievement of $38 \%$, by 2018 by $43 \%$ and amounted to $69.09 \%$ in 2019 . Increased percentage in 2017 to 2018 amounted to only $5 \%$. Nevertheless, it can be seen in the 2018 to 2019 increased by $26.09 \%$. This suggests that entrepreneurship development programs implemented in STKIP PGRI Nganjuk going well. One of the programs is the application of curriculum and innovative learning model-based product. Model-based learning products provide opportunities for students to explore as much information as possible from the surrounding environment. A lot of knowledge and skills in entrepreneurship gained from the business environment (Moustaghfir, K., \& Sirca, NT (2010). Good entrepreneurial skills should use teaching methods that allow students to engage in practical skills and real (Esene, RA (2015).

In addition to the implementation of projectbased learning model, lecturers also prepared entrepreneurship development programs through Creative Products Bazaar. The program is carried out as the highlight of the whole process of learning activities. In this bazaar activity, all students must attend and display their products. There were about 65 booths of products and attended by about 550 consumers and creative business owners outside the campus. Through this program, the spirit of entrepreneurship, creativity and innovation of students in creating products increases. Continuous application of innovative programs based products and implementing the concept of conceptual learning can improve student interest (Mopangga, H. (2014). Even students have a high initiative in promoting the products both offline and online through social media. Social networking is useful in facilitating business, developing entrepreneurial intention, to get information and advice. Thus, someone who has a social networking would be easy to obtain assistance or advice in the undertakings to support the success of businesses owned (Zafar MJ, Yasin, G., and Ijaz, M. (2012); Daim, T., Chen, WY, Weng, CS, \& Hsu, HY (2010).

\section{Conclusion:}

Implementation of curriculum and innovative learning model is very supportive in promoting entrepreneurial skills. Evidently, the implementation of project-based learning models are effective in foster entrepreneurship students with statistical results showed an effect of $75.1 \%$, while $24.9 \%$ are influenced by 
other variables not examined. In general, the results showed the soul entrepreneurship students in the high category. Achievement soul entrepreneurship can be observed based on nine indicators that is confident and optimistic, task-oriented and results, dare to take risks, have the leadership, has originality, futureoriented, desire to move forward, curiosity is strong, and has the spirit of abstinence give up high.

The need for innovative learning model that is able to improve the skills of students so ready to plunge into the community, the need for planting entrepreneurship spirit in students so that they can grow character students who are ready to make the job search and unemployment, the need for entrepreneurial education and business incubation at each campus for the sake of supporting nation economic. The programs that are improving business skills need to be done so that students are accustomed too. So that experience that belonged will increase.

\section{References}

[1] Vanevenhoven, J., \& Liguori, E. (2013). The impact of entrepreneurship education: Introducing the entrepreneurship education project. Journal of Small Business Management, 51 (3), 315-328.

[2] Ayobami, AP, \& Olakitan, OO (2011). An investigation of personality on entrepreneurial success. Journal of Emerging Trends in Economics and Management Sciences, 2 (2), 95-103.

[3] Pazhani, SS, and Priya, TS (2012). Need for soft skills development towards managerial efficiency. International Journal of Management Research and Reviews, 2 (11), 1895.

[4] Lukic, J. (2012, September). Creativity and innovation as the driving power of entrepreneurship. In Proceedings in EIIC-1st Electronic International Interdisciplinary Conference (No. 1).

[5] Sani, RA (2014). Scientific Learning curriculum for implementation in 2013.

[6] Wurdinger, S., \& Qureshi, M. (2015). Enhancing college students' life skills through project-based learning. (Abstract). Innovative Higher Education, 40 (3), 279-286.

[7] Naderi, N., Saeed, R., \& Ahmad, RNI (2013). Explaining The Role Of Education Quality In University Entrepreneurship: Based On Grounded Theory. Asian Journal of Management Sciences and Education, 2 (4), 128-135.

[8] Directorate-General. (2008). Entrepreneurship education in higher education, especially within non-business studies. In the EC Directorate-General for Enterprise and Industry (Ed.), Final report of the expert group. European Commission, Brussels. 
[9] Lindh, I., \& Thorgren, S. (2016). Entrepreneurship education: the role of local business. Entrepreneurship \& Regional Development, 28 (56), 313-336.

[10] Roche, K. (2014). Job satisfaction and the educated entrepreneur. Journal of Small Business and Entrepreneurship, 27 (4), 353-368.

[11]Ravitz, J., Hixson, N., English, M., \& Mergendoller, J. (2012, April). Using project-based learning to teach 21st century skills: Findings from a statewide initiative. In the American Educational Research Association Conference, Vancouver, Canada (Vol. 16).

[12] Wurdinger, S., \& Qureshi, M. (2015). Enhancing college students' life skills through project-based learning. Innovative Higher Education, 40 (3), 279286.

[13] Sunarya, A., Sudaryono, and Saifullah, A. (2011). Entrepreneurship (Entrepreneurship). Yogyakarta: Andi Offset.

[14]Zimmerer, TW, Scarborough, NM, \& Wilson, D. (2008). Essentials of entrepreneurship and small business management (5th Edition). [Translated by Kwary, DA \& D Fitriasari. Entrepreneurship and Small Business Management.] Jakarta: Four Salemba.

[15]Lillian, B. 2012. Scaffolding Teachers Integrate Social Media Into a Problem-Based LearningApproach. The Electronic Journal of $e$ Learning, 10 (1), 13-22.
[16] Primary, H., \& Prastyaningrum, I. (2019, February). Effectiveness of the use of Integrated Project Based Learning model, the telegram messenger, and plagiarism checker on learning outcomes. In the Journal of Physics: Conference Series (Vol. 1171, No. 1, p. 012 033). IOP Publishing.

[17] Kusmintarti, A., Thoyib, A., Maskie, G., \& Asr, K. (2016). Entrepreneurial characteristics as a mediation of entrepreneurial education influence on entrepreneurial intention. Journal of Entrepreneurship Education, 19 (1), 24.

[18] Greenberg J. \& Baron, RA (2008). Behavior in organizations (Ninth Edition). New Jersey: Pearson Education.

[19]Zarei, E., Zainalipour, H., \& Shahraki, LS (2013). Relationship between achievement motivation and ambiguity tolerance with entrepreneurship among students in Hormozgan University. Journal of Educational and Management Studies, 3 (2), 167172.

[20] Moustaghfir, K., \& Sirca, NT (2010). Entrepreneurial learning in higher education: introduction to the thematic issue. International Journal of Euro-Mediterranean studies, 3 (1), 3-26.

[21]Esene, RA (2015). Implementation of entrepreneurship education curriculum development of Polytechnic education towards reduction in unemployment among graduates of office technology and management in the nigerian South-South zone. European Journal of Research and Reflection in Management Sciences Vol, 3 (1). 
IJAMSR 3 (2) www.ijamsr.com CrossRef: https://doi.org/10.31426/ijamsr.2020.3.2.3112

[22] Mopangga, H. (2014). The determinant factor Interests Entrepreneurial Student Faculty of Economics and Business, University of Gorontalo. Trikonomika, 13 (1), 78-90.

[23]Zafar, MJ, Yasin, G., \& Ijaz, M. (2012). Social networking is a source for developing entrepreneurial intentions among entrepreneurs: A case of Multan. Asian Economic and Financial Review, 2 (8), 1072.

[24] Daim, T., Chen, WY, Weng, CS, \& Hsu, HY (2010). A study of the entrepreneurship of Taiwanese youth by the Chinese Entrepreneur Aptitude Scale. Journal of Technology Management in China, 